\title{
Competency Matrix for Medical Residency Programmes in Endocrinology and Metabolism
}

\section{PALAVRAS-CHAVE \\ - Educação Médica. \\ - Matriz de Competências. \\ - Residência Médica. \\ - Endocrinologia. \\ - Currículo.}

\section{Matriz de Competências para Programas de Residência Médica em Endocrinologia e Metabologia}

Ana Augusta Motta Oliveira Valente ${ }^{1 \odot}$ Milena Coelho Fernandes Caldato ${ }^{I, I I}$

\begin{abstract}
RESUMO
Introduction: Competências médicas tornaram-se o ponto central em todos os níveis na educação médica ao redor do mundo. Nesse contexto, Programas de Residência Médica (PRM) no Brasil têm começado a buscar um currículo baseado em competências para aprimorar a formação do especialista. Objetivo: Elaborar uma proposta de Matriz de Competências para Programas de Residência Médica em Endocrinologia e Metabologia (MREM). Metodologia: O estudo foi dividido em quatro fases. A primeira fase consistiu na revisão bibliográfica e construção da Matriz Piloto. Na segunda fase, em encontro presencial, aplicou-se a Matriz Piloto a endocrinologistas, com posterior análise dos dados e construção da Matriz Estruturada. Na terceira fase, aplicou-se a Matriz Estruturada no Congresso Brasileiro de Endocrinologia e Metabologia (CBEM 2016) a endocrinologistas, com um total de 49 respostas. Com base na metodologia Delphi, analisaram-se as 230 competências de cada uma das matrizes e criou-se um questionário contendo competências com divergência superior a 10\% e com as sugestões dos especialistas. Na quarta e última fase, também utilizando-se metologia Delphi, enviou-se por e-mail o questionário e realizou-se análise dos dados e construção da proposta MREM. Resultados: Na segunda, terceira e quarta fase, a taxa de resposta dos endocrinologistas foi de $73,3 \%, 51 \%$ e 76,4\%, respectivamente, tendo o Sudeste apresentado o maior número de participantes. A Matriz Piloto apresentava 219 competências, a Matriz Estruturada, 230, e a proposta final da MREM, 244. As áreas de competências Diabetes e Obesidade, Síndrome Metabólica e Alterações de Apetite tiveram as maiores modificações e sugestões. Em todas as fases, apenas duas competências foram excluídas. As sugestões da terceira fase foram unanimamente aceitas. Conclusão: A proposta de MREM finalizou com 21 áreas e 244 competências, 33 classificadas como pré-requisito, 157 como competência essencial, 36 como desejável e 18 como avançada. As competências distribuíram-se da seguinte forma na MREM: campo "Fundamentos" - 100 competências, 15 pré-requisitos, 65 competências essenciais, 14 desejáveis e 6 avançadas; campo "Conhecimento Específico" - 132 competências, 18 pré-requisitos, 87 competências essenciais, 19 desejáveis e 8 avançadas; e campo "Formação Complementar" - 12 competências, nenhum pré-requisito, 5 competências essenciais, 3 desejáveis e 4 avançadas. A MREM foi aprovada pela Comissão de Formação em Endocrinologia e Metabologia da SBEM e submetida a avaliação no Ministério da Educação (MEC), sendo utilizada como base para a Matriz de Competências de Endocrinologia e Metabologia, publicada pelo Conselho Nacional de Residência Médica (CNRM).
\end{abstract}

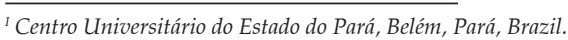

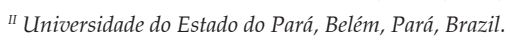




\section{KEY-WORDS}

- Medical Education.

- Competency Matrix.

- Medical Residency.

- Endocrinology.

- Curriculum.

\begin{abstract}
Introduction: Medical competencies have become the focus of Medical Education at all levels around the world. In this context the Medical Residency Programs (MRP) in Brazil have begun to seek a competency-based curriculum to improve the specialist training. Objective: To develop a proposed Competency Matrix for Medical Residency Programs in Endocrinology and Metabolism (MREM). Methodology: The study was divided into four phases. The first phase consisted of a bibliographical review and construction of the Pilot Matrix. In the second phase the Pilot Matrix was applied to endocrinologists from Belém, with subsequent data analysis and construction of the Structured Matrix. The third phase started with the implementation of the Structured Matrix at the Brazilian Congress of Endocrinology and Metabolism - CBEM 2016 with a total of 49 responses. Based on the Delphi methodology, the 230 competencies of each one of the matrices were analyzed and a questionnaire containing competences with a discrepancy level greater than $10 \%$ was created, including some suggestions from the experts. In the fourth and last phase, also using Delphi methodology, the questionnaire was sent by email and data analysis and construction of the MREM proposal was performed. Results: In the second, third and fourth phases, the response rate of Endocrinologists was $73.3 \%, 51 \%$ and $76.4 \%$, respectively. With the Southeast region of Brazil presenting the largest number of participants. There are 219 competencies in the Pilot Matrix, 230 in the Structured Matrix and 244 in the final MREM proposal. The competency areas of Diabetes and Obesity, Metabolic Syndrome and Alterations of Appetite were those which showed major change and suggestions. In all phases, only 2 competencies were excluded. The suggestions made in the third phase were unanimously accepted. Conclusion: The MREM proposal was concluded with 21 areas and 244 competencies, 33 classified as prerequisites, 157 as essential competencies, 36 as desirable and 18 as advanced. The competencies were distributed as follows in the MCPRMEM: "Fundamental" field with 100 competencies, with 15 prerequisites, 65 core competencies, 14 desirable and 6 advanced ones; "Specific Knowledge" field with 132 competences, with 18 prerequisites, 87 essential competences, 19 desirable and 8 advanced; and "Complementary Training" field with 12 skills, no prerequisites, 5 core competencies, 3 desirable and 4 advanced skills.
\end{abstract}

Received on 19/3/2019

Accepted on 3/6/2019

\section{INTRODUCTION}

Medical competencies are a key component of medical education at all levels, worldwide. However, the lack of precise characteristics that clearly define what a competency actually consists of raises questions and discussions ${ }^{1.2}$.

Competence was initially defined as a synthesis of knowledge, skills and attitudes that, when used together, enable the individual to maximize the use of cognitive and technical resources to diagnose, treat and provide benefits, decrease patient morbidity, and lower the costs for institutions. These resources should be consistent with professional ethics, with the best scientific evidence available, and with personal experience ${ }^{2}$.

In view of the need to train professionals with a contemporary, competency-based profile, at the beginning of the 21st century, the National Curricular Guidelines (NCG) were im- plemented in Brazil for Undergraduate Courses in Medicine (UCM). It was hoped that this would bring about a change in the traditional curricular model of undergraduate courses, which tended to be structured around "grades" and characterized by excessive rigidity, largely due to an overly detailed and almost exclusive focus on discipline contents ${ }^{3}$.

In April 2014, the NCG were updated, with the aim of ensuring more flexibility, diversity and quality in the training offered to students, preparing future graduates to meet the challenges posed by the rapid transformations in society, in the job market, and in the professional practice environment. The NCG therefore proposed a new professional profile, based on the development and assessment of competencies ${ }^{4}$.

However, for the majority of Medical Residency Programmes (MRP) that received graduates who had trained 
based on the NCGs updated in 2014, there were no proposed NCGs; access to the programmes, and the minimum requirements of each, were based on Resolution no. 02/2006 of the National Council of Medical Residency. It was only in 2018 that the Ministry of Education published competency matrices that were approved by the National Council of Medical Residency (Conselho Nacional de Residência Médica - CNRM) ${ }^{5-7}$.

As the construction of a competency matrix is a topic that still elicits discussions, the first to be published in Brazil, such as those of Family and Community Medicine and Occupational Medicine, were produced based on the Delphi method. This method was originally developed in California (USA) by Rand Corporation at the end of the 1950s to assist military decision-making in the area of future technologies, and in the international political context. Since then, the method has increasingly been employed and modified for application in different fields, such as information science, education, sociology and health ${ }^{8-10}$.

In January 2018, Brazil had 452,800 physicians, which is equivalent to 2.18 per thousand inhabitants. Of the total of 451,777 registered physicians in the country, $62.5 \%$ have one or more specialist titles, while $37.5 \%$ do not have any title ${ }^{11}$.

Endocrinology and Metabolism (EM) is a medical specialty that has become consolidated in Brazil since 1950, with the establishment of the Brazilian Society Endocrinology and Metabolism (SBEM - its acronym in Portuguese). In 1968, an agreement was signed with the Brazilian Medical Association (AMB) to create the official title of specialist in Endocrinology and Metabolism. Today, the SBEM is one of the three largest societies in terms of the number of members worldwide, and there is increasing demand for the specialist in MRP, for which a pre-requisite is two years in the area of Clinical Medicine $e^{9.12}$.

Of the 55 recognized Brazilian medical specialties, EM is in 19th position in terms of the number of physicians, with 5,210 endocrinologists registered under the title of specialist or as medical residents ${ }^{11}$.

According to 2009 data from the Ministry of Education (MEC), there are $56 \mathrm{MRPs}$ in Brazil, offering around 130 places per year. This figure is probably outdated due to the incentives offered in recent years by the federal government to expand the number of MRPs in the country. According to SBEM data for September 2016, there are 56 accredited services, offering 144 places per year, as well as 18 postgraduate services accredited by the SBEM, which offer 72 places per year.13.

According to the SBEM, the areas in which the endocrinologist works are: andropause, cholesterol and triglycerides, diabetes, menstrual disorders, disorders of puberty, disease of the adrenal and pituitary glands, overweight, obesity, os- teoporosis, menopausal hormone replacement, and thyroid changes. It is a specialty in which practitioners work predominantly in the outpatient and emergency departments ${ }^{14}$.

Contradicting the above, National Medical Residency Council Resolution no. 02/2006, which regulated the creation and implementation of MRPs in EM, summarised the criteria as follows: hospital admission unit (minimum of $30 \%$ of the annual workload); clinic (minimum of $20 \%$ of the annual workload); urgent and emergency care (minimum of $15 \%$ of the annual workload); hormones, radioimmunoassay and pathology laboratory (minimum of $15 \%$ of the annual workload); installations and equipment, hormones and radioimmunoassay and nuclear medicine service ${ }^{6}$.

Due to the need to update and standardise the creation and monitoring of MRPs, given that undergraduate courses in medicine have competency-based NCGs, the CNRM called upon the medical specialties to present competency matrices, which were approved and published in 2018. In the specialty of $\mathrm{EM}$, the published matrix was based on the competency matrix of the present work, which had already been approved by the SBEM Training Committee in Endocrinology ${ }^{13}$, with the advantage that it had to follow the rules of the CNRM matrices, which separate the competencies of medical residents in the first and second years of residency rather than by levels of competence ${ }^{7}$.

\section{PURPOSE}

To create a proposed Competency Matrix for Medical Residency Programmes in Endocrinology and Metabolism.

\section{METODOLOGY}

For the construction of this proposed Competency Matrix for Medical Residency Programmes in Endocrinology and Metabolism (MREM), we performed a literature review and a bibliographic survey of existing matrices in Latin America, the United States, Canada and Europe. Following this evaluation, competencies that featured in the majority of the matrices were selected, and a Pilot Matrix was created, which grouped the common competences of each subarea in EM and aspects related to the general training of this medical specialist.

Based on the fact that in Brazil, numerous Medical Residency Programmes were implemented without the due preparation of the preceptors to train apprentices, and without adequate infrastructure, the proposed matrix was conceived with the aim of establishing an MREM, which was presented to the preceptors and those responsible for Brazilian Medical Residency Programmes in EM, serving as support for the process of formation and training of medical residents. Regional diversities and their different characteristics were taken into 
account, as well as their human resources capacities and economic limitations, in order to create a programme that would be successful in at least the majority of the available services.

This competency matrix is therefore structured based on three pillars: Field, Group, and Area of Competence. Field is divided into: Foundations, Specific Knowledge, and Complementary Training.

The field "Foundations" has three groups: Theoretical Foundations, Foundations of practice and Management. Each group is subdivided into ten Areas of Competence.

The field "Special Knowledge" has one group, "Endocrinology and Metabolism", with ten areas of competence.

The field "Complementary Training" has a Group and Area of Competence with the same name: "Complementary Training".

In each of the 21 Areas of Competence, specific competencies were listed, and distributed within the matrix through the following items: pre-requisite, essential competency, desirable competency, and advanced competency, which can be understood as follows:

- Pre-requisite: competencies gained in undergraduate medical school or the residency in clinical medicine, i.e., the competencies expected of the professional before entering the residency in EM;

- Essential: competencies expected of all residents at the end of their training as endocrinologists;

- Desirable: competencies expected of an outstanding resident, who has advanced beyond the essential competencies for an endocrinologist;

- Advanced: specific knowledge, which can be acquired through complementary courses.

The matrix was drawn up as a table, with the above items distributed horizontally and the competencies described individually, each within its respective level. Competencies with the same line of reasoning, but with graduation at different levels, remained on the same line. Beside each line with the competency(ies), there was a space for the respondent to write "agree" or "disagree" with the competency in question, as well as with its level of classification. There was also space for suggestions or comments.

The study presented the four phases described below.

\section{First Phase}

Consisted of the elaboration of a Pilot Matrix with 21 areas and 219 competencies, classified as follows: 29 pre-requisites, 140 essential competencies 35 desirable competencies, and 15 advanced competencies.

\section{Second Phase}

The Pilot Matrix was submitted to 15 endocrinologists at a face-to-face meeting of the SBEM - Pará Region, to promote greater adherence to the matrix, and discussion of the items (all the participating endocrinologists had teaching practice in EM, either as university lecturers or as medical residency preceptors). Eleven of the 15 matrices distributed for analysis were returned. After evaluation of the Pilot Matrix by these specialists, some suggestions and modifications were made and a new Matrix, known as the Structured Matrix, was created. In this new Matrix, 21 of the areas and a total of 230 competencies were retained. These were distributed as follows: 31 pre-requisites, 145 essential competencies 36 desirable competencies, and 18 advanced competencies.

\section{Third Phase}

With the support of the national SBEM, which in its 32nd Brazilian Congress, held from $20^{\text {th }}$ to $24^{\text {th }}$ September 2016 in Costa do Sauípe (BA), a round table was held on medical training, with a specific lecture on medical residency, in which the participants agreed to help evaluate the Structured Matrix. To participate in this phase, the only criterion used was that the participant had to be an endocrinologist. Ninety-six Matrices were distributed, of which 49 were returned.

A total of 230 competencies for each of the matrices were evaluated. The reanalysis criterion was adopted for competencies for which there was disagreement of more than $10 \%$. This was because, although there is no absolute value of agreement for an item to be considered consensual, the authors of the study adopted agreement of more than $90 \%$ as the minimum acceptable criterion. Discordant competencies and/or those suggested by the specialists were grouped together, and a questionnaire was created to facilitate the participation and streamline the responses, using the Delphi method in the last two stages.

The Delphi method starts with the selection of a group of informants who are familiar with the topic, or socialized with the context being investigated. A questionnaire with exploratory characteristics is then applied to the informants. This questionnaire is designed to gather preliminary information that will be analysed, comprising the first round. Based on the questionnaires answered and analysed in the first round, a second questionnaire is generated, which is returned so that the specialists can respond to the new questions, constituting the second round. The rounds are repeated until a consensus is reached ${ }^{15}$. 


\section{Fourth phase}

This phase consists of the application of the questionnaire with points of disagreement, and suggestions, based on the Delphi method. A smaller group of specialists was selected based on the following criteria: they had to be from different regions of Brazil in order to reduce regional disparities; they must have participated in the third phase of the work, and therefore have knowledge of the content; and they must be a professor or teaching preceptor (undergraduate or graduate) in EM.

Seventeen questionnaires were sent by email, according to the criteria cited above. Of these, 13 were returned. After analysing the responses, a definitive proposal for MREM was elaborated, which was presented to the SBEM.

According to National Health Council Resolution no. 510 of $7^{\text {th }}$ April 2016, this work does not require submission to a Research Ethics Committee because it is based on a review of scientific texts and does not identify the subjects who responded to the different stages in the construction of the proposed MREM.

\section{RESULTADOS}

The Pilot Matrix presented 219 competencies, as follows: 29 pre-requisites, 140 essential competencies, 35 desirable competencies and 15 advanced competencies. This matrix was evaluated by 11 endocrinologists, representing a response rate of $73.3 \%$. Chart 1 shows the modifications and suggestions gathered.

Of the 96 Structured Matrices, 49 were returned (51\% response rate). These were distributed by region as follows: Southeast 15 (30.61\%), North and Northeast 12 (24.49\%), Central-west $6(12.25 \%)$ and South $4(8.16 \%)$.

Of the 230 competencies, those that showed disagreement of more than $10 \%$ were grouped and subjected to further analysis by a smaller group of specialists (Table 1).

In addition to the competencies for which there was disagreement of over $10 \%$, other competencies were suggested by the participants in this phase, which were also added for analysis in the fourth stage of the work. These are presented in Table 2.

In the fourth phase, using the Delphi methodology, questionnaires with competencies that had disagreement of over $10 \%$, and the suggestions, were sent out to 17 endocrinologists. Responses were obtained from 13 of them - a response rate of $76.5 \%$, distributed by region as follows: Southeast $4(30.7 \%)$, North 3 (23.1\%) Northeast and Central-West 2 (15.4\%).

Of the 41 competencies sent in the questionnaire, 25 were for new analysis, as they were already part of the Structured Matrix, and 16 were added as suggestions in the third stage.
Considering the simple majority, of the 25 competencies examined, 5 were retained as proposed in the structured matrix, 2 were excluded from the Matrix, and 17 were classified in different levels of competencies. One competency showed no majority agreement, and therefore remained at its initial level.

Table 3 describes the 17 competencies that were modified. Arrows are used to illustrate the modification of levels of competence; the tip of the arrow shows the current level, and the other end, the previous level of competence.

The only competence for which a consensus could not be reached in terms of its level was performing fundoscopy, so it remained as an advanced competence, as in the Structured Matrix.

Of the 16 competencies suggested in the third stage, 50\% were in the area of "Obesity, Metabolic Syndrome and changes in appetite." Of these 16 competencies, only 5 were changed to a different level, leaving the remaining 11 as suggested by the specialists. Table 4 describes these competencies.

\section{DISCUSSION}

The elaboration of a competency-based curriculum involves, at the start, defining a competency matrix, i.e. a set of key competences to be developed throughout the educational programme. Next, it is necessary to define the components of these competencies, and then, the levels of performance to be achieved in each year or period of the curricular development. Alongside this definition of competences and their components, we are defining the system of evaluation of results and processes ${ }^{16}$, to meet the stages performed in this study.

The response rate of specialists ranged from $51 \%$ to $76.5 \%$ during the phases of this study, a higher percentage than the $7-13 \%$ found by Galan And Vernete ${ }^{17}$. This is probably because it is a subject of interest to endocrinologists, and because some of them are involving in teaching the speciality. This corroborates the literature, which states that the response rate depends on the respondent's level of interest in the research being conducted ${ }^{17.18}$.

The creation of a Competency Matrix is controversial, and there is no universally accepted model. The ACGM - Outcome Project proposes six areas of competence and some methods for their evaluation: Patient care; medical knowledge; practice-based learning; interpersonal and communication skills, professionalism, and systems-based practice. Meanwhile, the Competency Matrix established by the Brazilian National Association of Occupational Medicine defines six essential areas of competency as the basis, presenting, as the central point, the professionalism or competency of moral judgment. 


\section{Chart 1}

\section{Suggestions for adding to or modifying the Pilot Matrix}

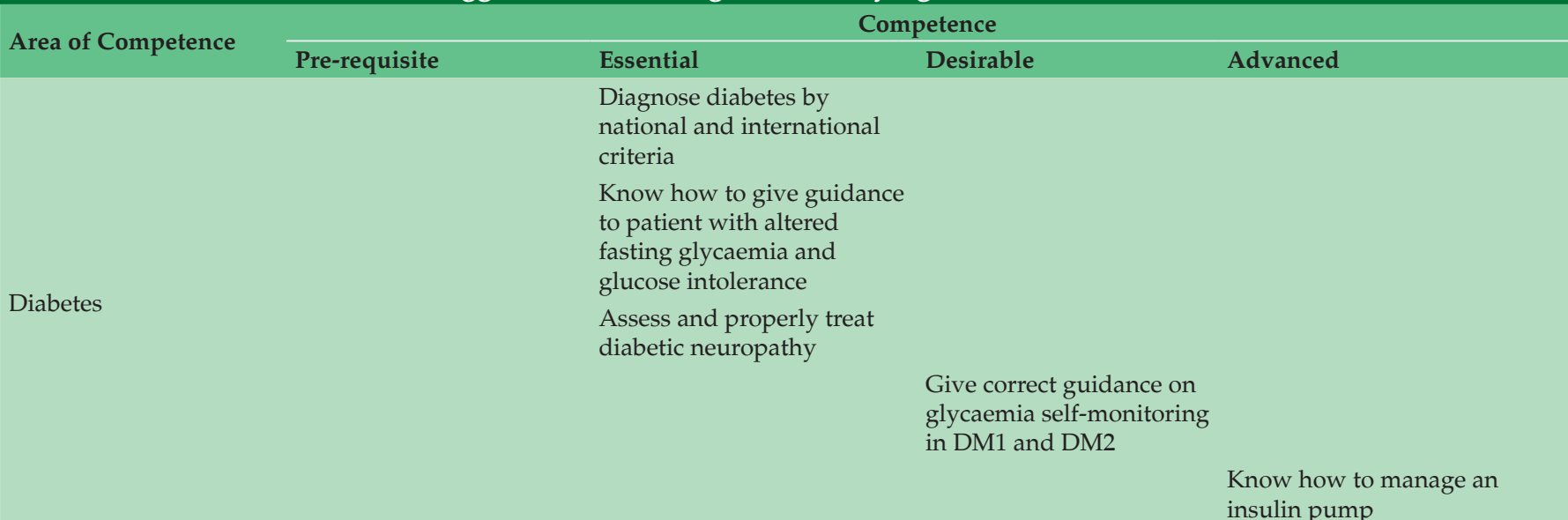

Thyroid

Have a basic notion of thyroid ultrasound and treatment with percutaneous ethanol injection

Identify the carpal and hand bones for proper evaluation of bone age X-rays, through

Endocrinopediatria the Greulich Pyle method

Know how to perform the final stature prediction calculation by the BayleyPinneau method

\section{Metabolism of calcium} and bone
Understand and interpret imaging methods used in bone pathologies

\section{Metabolism of lipids \\ Correlate insulin \\ Gonads resistance with pathophysiology and the treatment of polycystic ovary syndrome \\ Obesity, metabolic syndrome and changes in appetite \\ Understand the pathophysiology of metabolic syndrome and know how to diagnose it}

Identify and properly

treat familial

hypercholesterolaemia

Note: The arrow signifies a change in the level of competence, from desirable to essential. Source: Data from the work itself.

The present study, unlike the models mentioned, was based on the construction of levels of competence, which can be acquired at any time in the RM of EM, and can also be seen in the competence-based curriculum for Family and Community Medicine. This model allows continuous learning, and enables the MRP to place the resident in an area of practice, as they can be switched to different areas of practice during the two years of the programme.
The validation of MREM was guided by the Delphi method and by the Competency Matrices defined for Occupational Medicine and Family and Community Medicine.

The aim of the Delphi method is to obtain the consensus of a selected group of specialists on certain issues, with the formation of a qualified collective opinion ${ }^{10}$. In education, the Delphi technique has been used to select competencies, objectives, course content, or curricular disciplines of courses in the 
TABLE 1

Description of competencies with disagreement of more than $10 \%$, in ascending order, by area of competency

Area of Competency

Analyse the context in which Supplementary Health was introduced

Supplementary Health

Know how to analyse the remuneration tables of remuneration of this system

Individual and Family approach

Identify cases of family violence and forward properly

14.28

Communication skills

Use media resources relevant to their clinical practice

10.20

Continuing Education

Know how to give up-to-date oral accounts with appropriate content

10.20

Carry out research projects

18.36

Competencies in medical research, management and teaching

Participate as a medical research collaborator in EM

18.36

Office management and

Course in administrative management

20.40

organization of the work process

Develop spreadsheets of expenses and gains for financial planning

26.53

Multidisciplinary Team work

Perform service in conjunction with the multidisciplinary team

22.44

Perform fundoscopy

10.20

Know how to perform dose escalation of medications for each type of patient

16.32

Know how to give guidance on diet and physical activity

20.40

Diabetes

Explain carbohydrate counting to insulin-dependent patients

20.40

Know how to manage an insulin pump

20.40

Give correct guidance on glycaemia self-monitoring in DM1 and DM2

Hypothalamus and pituitary

Participate in catheterization of the petrosal sinus

22.44

Thyroid

Participate in a multidisciplinary team with head and neck surgeons

14.28

Endocrinopediatria

Know how to perform the final stature prediction calculation by the Bayley-Pinneau

32.65

Metabolism of calcium and bone

Metabolism of lipids method

Obesity. metabolic syndrome and changes in appetite

Recognize and know how to differentiate bulimia and anorexia nervosa

40.81

Miscellaneous*

Properly manage endocrine and metabolic disorders in HIV infection

14.28

Identify slide staining methods and the preparation of material for pathology

Complementary Training

Make FNA [Fine-needle aspiration] slides of the thyroid

* Miscellaneous: groups of subjects or topics not included in other areas of Endocrinology.

Source: Data from the work itself.

area of health, especially in Medicine and Nursing ${ }^{19}$. The number of specialists involved in a Delphi Group has a direct effect on the potential for new ideas to be considered, as well as on the generation of information and the amount of information that the researcher intends to study ${ }^{20}$.

However, there is no consensus, in academic circles, on the ideal number of participants in a Delphi group. Rather, it depends on the scope and context of the research, ${ }^{21}$ and on factors extrinsic to the researcher, such as the availability of specialists to participate ${ }^{22}$. Generally, numerous groups are formed, and the most important thing is to ensure the quality of the sample, since the technique is highly sensitive to the motivation of participants and their knowledge about the subject being researched ${ }^{23}$.

The Delphi technique has a flexibility that allows considerable diversity in its application. Thus, it has been simplified when applied in some studies and research, especially those where the time variable needs to be controlled. The most frequent modification is the search for consensus. In the conventional form of the technique, the five steps are subsequentially repeated, and the specialists are asked to reconsider based on the result of the previous step until a consensus is reached. 


\begin{tabular}{|c|c|}
\hline & $\begin{array}{l}\text { TABLE } 2 \\
\text { Suggested competences for introduction to the Matrix }\end{array}$ \\
\hline Area of Competence & Suggested competencies \\
\hline Continuing Education & Know how to conduct medical research on platforms such as Pubmed and Medline \\
\hline $\begin{array}{l}\text { Competencies in medical } \\
\text { research, management } \\
\text { and teaching }\end{array}$ & $\begin{array}{l}\text { Submit a residency conclusion work, preferably in the form of an article already accepted for publication in an } \\
\text { official/scientific magazine }\end{array}$ \\
\hline Office management and & $\begin{array}{l}\text { Have a knowledge of the CFM [Federal Medical Council] recommendations related to the use of the ICF in the } \\
\text { clinic }\end{array}$ \\
\hline $\begin{array}{l}\text { organization of the work } \\
\text { process }\end{array}$ & Know about taxes and fees payable on medical work \\
\hline & Be aware of the Anvisa recommendations on disposal of medicines and biological material \\
\hline Disboto & Know how to manage diabetic ketoacidosis and hyperosmolar coma \\
\hline Diavetes & Know how to manage diabetic foot \\
\hline Metabolism of lipids & $\begin{array}{l}\text { Know how to manage cardiovascular risk through examinations such as ultrasound, echocardiogram with Doppler } \\
\text { of the carotid arteries, coronary calcium score and ankle-brachial index, when necessary }\end{array}$ \\
\hline & Check abdominal circumference, waist-hip ratio and their clinical applications \\
\hline & Identify clinical characteristics of the major causes of syndromic and monogenic obesities \\
\hline & Know the molecular changes of the main causes of obesity monogenic syndromic and \\
\hline Obesity, metabolic & Know how to evaluate the methods of diagnosis of obesity, such as bioimpedance and DEXA \\
\hline $\begin{array}{l}\text { syndrome and changes in } \\
\text { appetite }\end{array}$ & Assist in bariatric surgery, preferably laparoscopic \\
\hline & Calculate the basal metabolic rate and ideal weight \\
\hline & Perform nutritional survey and have a basic notion about diets \\
\hline & Apply criteria of metabolic syndrome in children and adolescents \\
\hline
\end{tabular}

Source: Data from the work itself.

In the so-called simplified Delphi technique, which was used in this study, a limit on the number of cycles of execution is proposed, with two to four cycles have being proposed in the search for consensus. Thus, the "consensus" represents the level achieved in the last determined step, usually at a cut-off point previously defined by the researcher ${ }^{19,24}$.

The Delphi Technique also has some disadvantages. We highlight the fact that the researchers could influence the results, whether in the formulation of the questions, which can lead them imposing their own points of view, or by ignoring and failing to exploit points of disagreement, generating an artificial consensus. In addition, some of the advantages of this technique could also be seen as disadvantages, such as the anonymity and feedback, which can lead the respondents to comply, opting simply to follow the response of the group, or else, to deliberately or inadvertently manipulate the results, leading false consensuses and distorted views. Finally, the amount of data generated by the Delphi questionnaires is large, which makes its analysis difficult, particularly in the open questions, and in cases where there is a large group of specialists $^{25-27}$.

The proposed MREM presented 25 competencies more than the Pilot Matrix. The majority of them (17) were in the area of essential competencies, which may demonstrate a con- cern of the specialists to train new residents with a minimum knowledge in the area of EM.

The final MREM can be accessed via the link: http:// www.cesupa.br/mestradoesem/docs/producao/ANA $\% 20$ AUGUSTA\%20PRODUTO.pdf

\section{CONCLUSION}

The finalised MREM had 21 areas and a total of 244 competencies; 33 pre-requisites, 157 essential competencies, 36 desirable competencies and 18 advanced competencies.

The competencies were distributed as follows in the MREM: field "Foundations - 100 competencies, 15 pre-requisites, 65 essential competencies, 14 desirable competencies and 6 advanced competencies; field "Specific Knowledge" - 132 competencies, 18 pre-requisites, 87 essential competencies, 19 desirable competencies and 8 advanced competencies; and in the field "Complementary Training - 12 competencies, no pre-requisite, 5 essential competencies, 3 desirable competencies and 4 advanced competencies.

The MREM was approved by Training Committee in Endocrinology and Metabolism of the SBEM, and submitted to evaluation by the Ministry of Education (MEC), using the Competency Matrix for Endocrinology and Metabolism published by the CNRM in 2018 as its basis. 
TABLE 3

Changes in levels of levels of competences in the finalised Matrix

\begin{tabular}{|c|c|c|c|c|}
\hline \multirow{2}{*}{ Area of Competence } & \multicolumn{4}{|c|}{ Competency } \\
\hline & Pre-requisite & Essential & Desirable & Advanced \\
\hline $\begin{array}{l}\text { Individual and Family } \\
\text { approach }\end{array}$ & $\begin{array}{l}\text { Identify cases of } \\
\text { family violence and } \\
\text { refer them properly }\end{array}$ & & & \\
\hline Continuing Education & & $\begin{array}{l}\text { Give up-to-date oral } \\
\text { presentations with appropriate } \\
\text { content }\end{array}$ & & \\
\hline
\end{tabular}

Office management and organization of the work process

\section{Working as part of}

multiprofessional team

Diabetes

Hypothalamus and

pituitary

Thyroid

\section{Endocrinopediatria}

\section{Metabolism of the}

calcium and bone

Metabolism of the lipids

Obesity, metabolic

syndrome and changes

in appetite

Give correct guidance to glycaemia self-monitoring in DM1 and DM2

Perform service in conjunction with the multidisciplinary team

Know how to perform dose escalation of medications for each type of patient and his / her social condition, and correlate the treatment with the pathophysiology of DM

Explain carbohydrate counting to insulin-dependent patients

Know how to give guidance on diet and physical activity$$
\text { in appetite }
$$

\section{Miscellaneous}

Identify and properly treat familial hypercholesterolaemia

Complementary

Training

Note: The tip of the arrow indicates the new level of the competence; the other end, the previous level.

Source: Data from the work itself.
Develop spreadsheets of expenses and gains for financial calculations
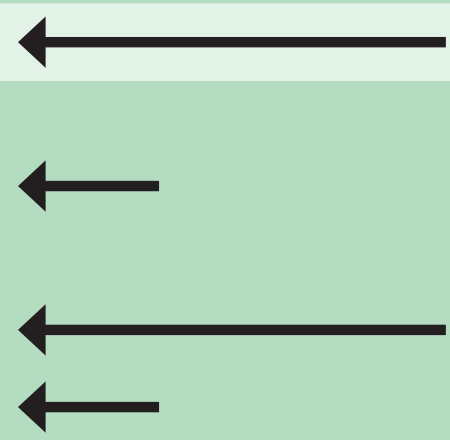

Know how to manage an insulin pump
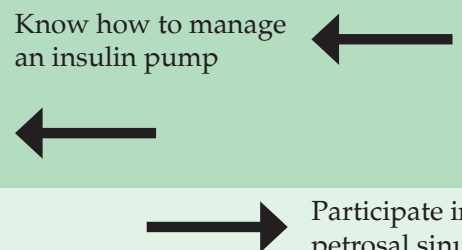

Participate in catheterization of the petrosal sinus

Participate in a multidisciplinary team with head and neck surgeons

Perform final stature prediction calculation by the Bayley-

Pinneau method
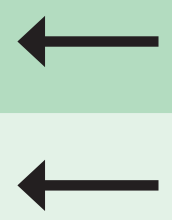

Know how to treat rare diseases of bone metabolism

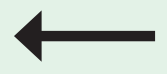

Recognize and know how to differentiate bulimia and anorexia nervosa

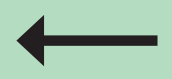

Properly manage

endocrine and

metabolic disorders

in HIV infection

Identify the slide staining methods and preparation of material for pathology 


\section{TABLE 4}

\section{Competencies suggested by specialists and retained in the finalised Matrix}

\begin{tabular}{ll} 
Area of Competence & \multicolumn{1}{c}{ Comp } \\
\cline { 2 - 3 } Continuing Education & \multicolumn{1}{c}{\begin{tabular}{c}
\multicolumn{1}{c}{ Essential } \\
Know how to conduct medical \\
research on platforms such as \\
Pubmed and Medline
\end{tabular}} \\
$\begin{array}{ll}\text { Competencies in } \\
\text { medical research, } \\
\text { management and } \\
\text { teaching }\end{array}$ & $\begin{array}{l}\text { Submit a residency conclusion } \\
\text { work, preferably in the form } \\
\text { of article already accepted for } \\
\text { publication in an official/scientific } \\
\text { magazine }\end{array}$ \\
\hline
\end{tabular}

Office management and organization of the work process

Diabetes

Metabolism of lipids

Obesity, metabolic

syndrome and changes

in appetite
Know about taxes and fees payable on medical work

Know how to manage ketoacidosis and Diabetic hyperosmolar coma

Know how to manage diabetic foot
Have a knowledge of the CFM

[Federal Medicine Council] recommendations related to the use of the ICF in the clinic Have a knowledge of the Anvisa recommendations on disposal of medicines and biological material

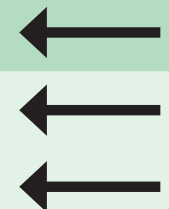

Know how to assess cardiovascular risk through examinations such as ultrasound, echocardiogram with Doppler of the carotid, coronary calcium score and ankle-brachial index, when necessary

Check abdominal

circumference, waist-hip ratio and its clinical applications

Calculate the basal metabolic rate and ideal weight

Perform nutritional survey and have basics notions of diets

Apply criteria of metabolic syndrome in children and adolescents
Identify clinical characteristics of the main causes of syndromic and monogenic obesities

Know the molecular alterations of the main causes of syndromic and monogenic obesity

Know how to evaluate the methods of diagnosing obesity, such as bioimpedance and Dexa

Watch bariatric surgery, preferably laparoscopic

Note: The tip of the arrow indicates the new level of competence and the other end, the previous level. Source: Data from the work itself. 


\section{REFERENCES}

1. Fernandes CR, Farias Son AG, Josenilia MA, Pinto Son WA, Cunha GKF, Maia FL. Skills based curriculum in medical residency. Brazilian Journal of Medical Education, 2012; 36(1):129-136.

2. Albanese MA, Mejicano G, Mullan P, Kokotailo P, Gruppen L. Defining characteristics of educational competencies. Med Educ., 2008;42(3):248-55.

3. Bollela VR, Machado JLM. Theoretical framework. Internship based on skills. Belo Horizonte: Medvance; 2010. p. 1-24.

4. Brasil. Ministry of Health. Guidelines for Integral care to people with rare diseases in the Single Health System SUS. 2014. Available at: http://bvsms.saude.gov.br/bvs/ publicacoes/diretrizes_atencao_integral_pessoa_doencas_raras_SUS.pdf. Accessed on: 18/07/2017.

5. Ribeiro MAA. Notes on the Medical Residency in Brazil. Brasilia: Chamber of Deputies, 2011. Available at: www2. camara.leg.br/documents-and-research/publicaoces/estnottec/areas of conle11/2011/theme_123.pdf. Accessed on: $27 / 05 / 2016$.

6. The National Council of Medical Residency. Resolution No 02 of 17 May 2006. Available at: portal.mec.gov.br/dmdocuments/resolucao02_2006.pdf. Accessed on: 10/03/2016.

7. Brasil. The Ministry of Education. Arrays of Competencies Approved by the CNRM. (C2018. Available at: http:/ / portal.mec.gov.br/component/content/article?id=71531. Accessed on: 07/01/2019.

8. Brazilian Society of Family and Community Medicine (SBMFC). Skills based curriculum for Family and Community Medicine. 2014. Available at: Http://www.sbmfc.org. br / media / Curriculo\%20Baseado\%20em\%20Competencias(1).pdf. Accessed on: 02/05/2016.

9. Brazilian Society of Endocrinology and Metabolism (SBEM). 2016. Available at: <www.endocrino.org.br/perfil-e-historia/>. Accessed on: 22/05/2016.

10. Oliveira JSP, Costa MM, Wille MFC. Introduction to Delphi Method. Curitiba: The material world; 2008. Available at: http:/ / eprints.rclis.org/12888/1/cartilha_delphi_digital. pdf. Accessed on: 15/07/2017.

11. Scheffer M, Biancarelli A, Cassenote A. Medical demography in Brazil 2015. São Paulo: The Federal Council of Medicine; 2015. Available at: http://mecsrv04.mec.gov.br/ sesu/SIST_CNRM/APPS/inst_especialidades.asp. Accessed on: $31 / 10 / 2015$.

12. Valle JP. History of the Brazilian Society of Endocrinology and Metabolism: Founded on 1.9.1950. ArqBrasEndocrinolMetab. 2002; 46(5): 582-592.
13. Brasil. The Ministry of Education. Until the adoption of the matrix in the CNRM. 2018. http:/ / portal.mec.gov.br/ docman/novembro-2018-pdf/102501-ata-da-10-sessao-ordinaria-cnrm-ul/file. Accessed on: 07/01/2019.

14. Brazilian Society of Endocrinology and Metabolism (SBEM). Fields of Endocrinology. 2009. Available at: https:/ / www.endocrino.org.br/areas-da-endocrinologia/. Accessed on: 22/05/2016.

15. Antunes MM. Delphi Technique: methodology for research in education in Brazil. Education Magazine PUC-Camp. 2014; 19 (1): 63-71

16. Santos AC. Management of human resources and delconocimiento: a diagnostic technology, planificaciónycontrol of strategic management. Revista de Ciencias Sociales. 2011; 17(2): 287-297.

17. Galan JP, Vernette E. Vers une 4èmè génération: les études de marché online. RevueDécisions Marketing. 2000;19: 3952.

18. de Freitas HMR, Janissek-Muniz R, Moscarola J. Use of Internet in the research process and data analysis. 2004. Available at: https://www.researchgate.net/publication/315706449_Uso_da_Internet_no_processo_de_ pesquisa_e_analise_de_dados. Accessed on: 13/07/2017.

19. Silva RF, Tanaka OY. Delphi Technique: identifying the general powers of doctors and nurses who work in primary care. Revista da Escola de Enfermagem da USP. 1999; 33(2): 207-216

20. Hasson F, Keeney S, Mckenna H. 2000. Research guidelines for the Delphi technique. JournalofAdvancedNursing, 32 (4): 1008-1015.

21. Vergara SC. Research methods in administration. 3. ed. São Paulo: Atlas; 2008.

22. Munaretto LF, Corrêa HL, Cunha JAC. A study on the characteristics of the Delphi method and focus group, as techniques in obtaining data in exploratory research. Revista de Administração UFSM. 2013; 6(1): 9-24.

23. Chiavegatto CV. Perception of upper-level professionals in Primary Care regarding the development of actions of health worker in SUS in Minas Gerais. Belo Horizonte; 2010. 128f. Master [dissertation] - Universidade Federal de Minas Gerais

24. Gontijo ED, Alvim C, Megale L, Melo JRC, Lima MECC. Array of skills essential for the formation and performance evaluation of medical students. Brazilian Journal of Medical Education. 2013; 37(4): 526-539.

25. Marques JBV, Freitas D. DELPHI method: characterization and potential in research in education. Pro-Positions. 2018; 29(2): 389-415. 
26. Powell C. The Delphi technique: myths and realities. J Adv Med. 2003;41(4):376-82.

27. Osborne J, Collins S, Ratcliffe M, Millar R, Duschl R. What "ideas-about-Science" should be taught in school science? The Delphi study of the expert community. Journal of Research in science teaching. 2003; 40 (7): 692-720.

\section{AUTHORS' CONTRIBUTIONS}

All authors participated in the conception of the work, data analysis, literature review and writing of the manuscript, approving the final version.

\section{CONFLICTS OF INTEREST}

The authors declare that they have no conflict of interest.

\section{ADDRESS FOR CORRESPONDENCE}

Ana Augusta Motta Oliveira Valente

Travessa 14 de março, 1155. Ed. Urbe 14, sala 807, Belém-PA, CEP: 66.055-490

E-mail: anaaugusta.endocrino@gmail.com 